\title{
Rarely seen complication of motor vehicle accidents: Bilateral globe avulsion
}

\author{
Osman Kelahmetoğlu, M.D., ${ }^{1 *}$ Tekin Şimşek, M.D., ${ }^{2}$ Ümit Beden, M.D., ${ }^{3}$ \\ İlhami Oğuzhan Aydoğdu, M.D., ${ }^{2}$ Ebru Cömert Hamzaoğlu, M.D. ${ }^{3}$
}

\author{
1Department of Plastic, Reconstructive and Aesthetic Surgery, Tarsus State Hospital, Mersin \\ ${ }^{2}$ Department of Plastic, Reconstructive and Aesthetic Surgery, Ondokuz Mayıs University Faculty of Medicine, Samsun \\ ${ }^{3}$ Department of Ophthalmology, Ondokuz Mayıs University Faculty of Medicine, Samsun
}

\begin{abstract}
Avulsion of the globe is a rare condition that can occur with severe maxillofacial trauma. A few bilateral cases have been reported. The objective of this study was to present a case of this challenging condition in a 15 -year-old male patient who was admitted to the emergency service after a motor vehicle accident.
\end{abstract}

Key words: Avulsion; globe; bilateral; luxation; trauma.

\section{INTRODUCTION}

Traffic accidents are the most common causes of maxillofacial trauma. Depending on the severity of the trauma, a wide spectrum of fracture patterns and unexpected conditions may be encountered like avulsion of the globe. Subluxation of the globe is extremely rare, and we found few reported cases. [1-3] This study presented the case of a patient with this rare condition, who was followed-up for one year postoperatively.

\section{CASE REPORT}

A 15-year-old male was admitted to the emergency service after a car accident. He had been sitting in the back seat. On examination, his entire face was edematous, the left up-

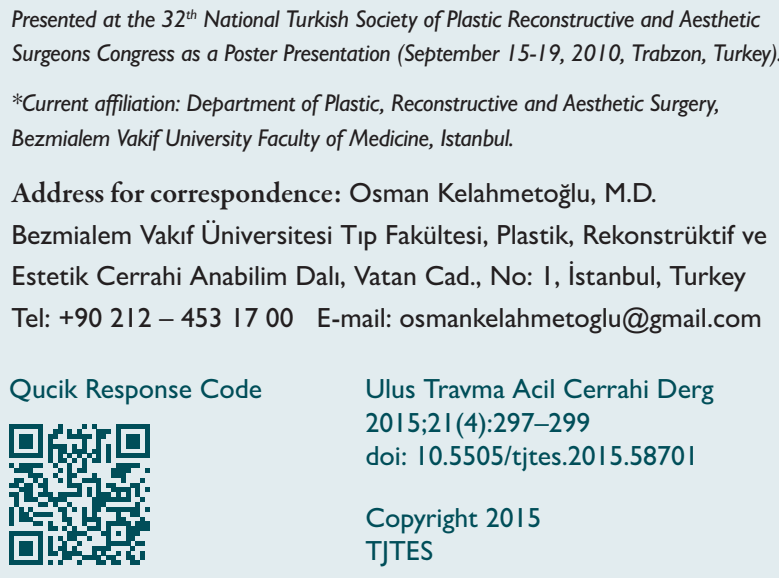

Address for correspondence: Osman Kelahmetoğlu, M.D. Bezmialem Vakıf Üniversitesi Tıp Fakültesi, Plastik, Rekonstrüktif ve Estetik Cerrahi Anabilim Dalı, Vatan Cad., No: I, İstanbul, Turkey Tel: +90 2I2 - 4531700 E-mail: osmankelahmetoglu@gmail.com

per lid had a deep laceration and both globes were luxated out of the orbital sockets (Figs. Ia,b). There were no light reflexes or any eye movement. Computed tomography (CT) showed complete laceration of both optic nerves (Fig. Ic). There were also multiple fractures corresponding to a Le Fort III pattern with Le Fort II components with frontal sinus anterior wall fractures. Neurosurgery consultation revealed no brain injury other than minor edema. The surgical team included an ophthalmologic surgeon. Radiological examination revealed no sign of systemic trauma, except minor brain swelling and pneumocephalus. There was no cervical injury.

After the initial evaluation in the emergency room, the patient was transferred to the operating room. The left globe was completely out of the orbit and there was retrobulbar hemorrhage; all extraocular muscles and optic nerve were ruptured. As the left globe was unsuitable for repositioning, it was enucleated. The right globe was also out of the orbit and had findings similar to the left globe, except there was no retrobulbar hemorrhage. The stumps of the medial and inferior rectus muscles were found. After repairing the medial and inferior rectus muscles and performing a right lateral canthoplasty, the globe was repositioned. The facial fractures were immobilized with plates and screws (Fig. Id). Postoperatively, the patient was observed in the intensive care unit for two days. He was discharged on the fifth postoperative day.

Four months postoperatively, the patient presented to the outpatient clinic with left periorbital cellulitis. He was treated with oral antibiotics. At six months, an ocular prosthesis was placed 

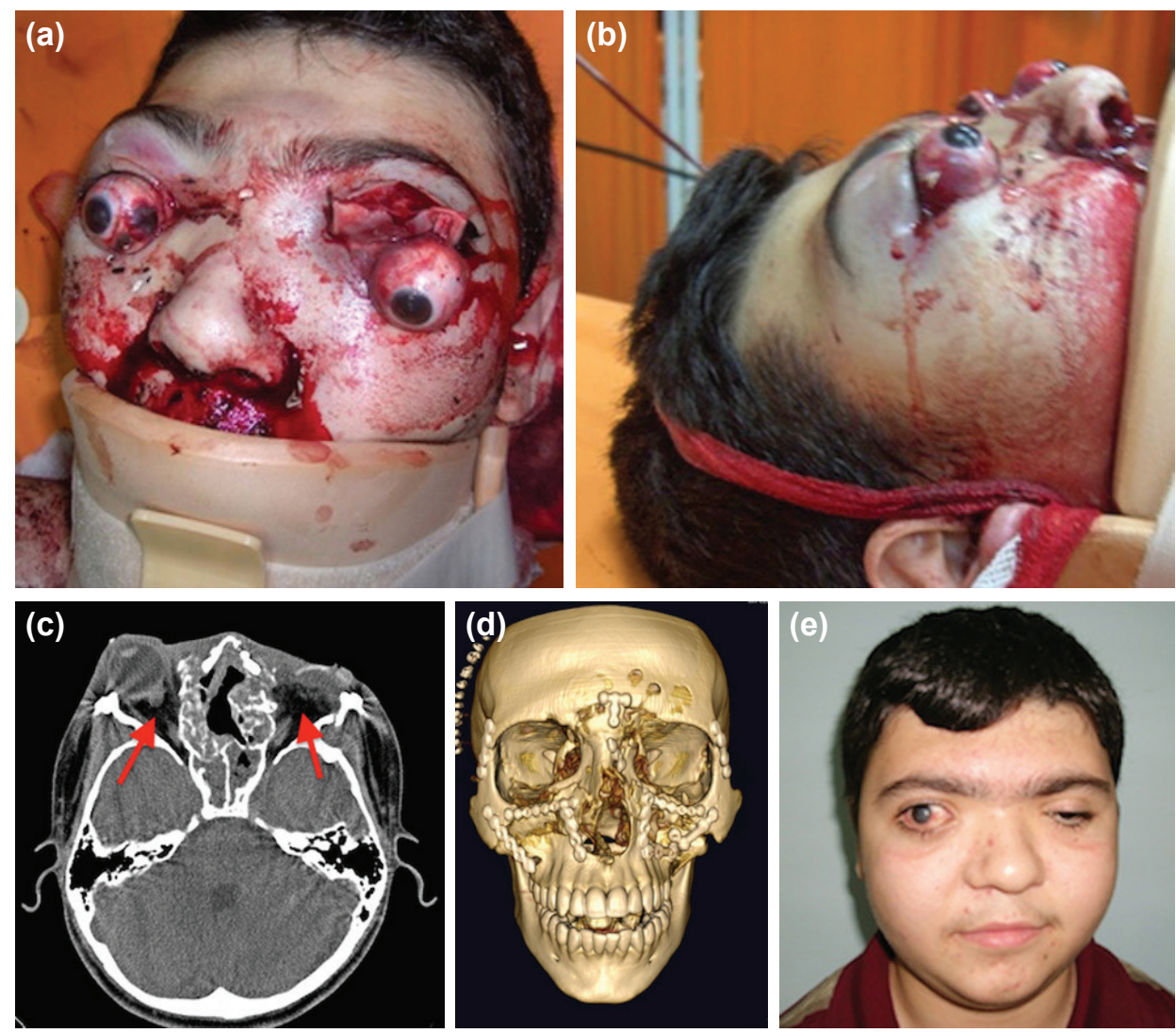

Figure 1. (a) Preoperative anterior view in the emergency room. (b) Preoperative lateral view in the emergency room. (c) Preoperative computed tomography scan imaging shows complete laceration of both optic nerves (red arrows). (d) Immediate postoperative 3D computed tomography imaging shows repaired facial fractures. (e) One year postoperative imaging shows no major facial deformity.

in the left orbit. One year postoperatively, the patient was reevaluated and there was no major facial deformity (Fig. Ie).

\section{DISCUSSION}

A variety of orbital and periorbital soft tissue injuries can be seen with craniofacial fractures, including contusion, avulsion, muscle entrapment, optic nerve damage, and globe rupture. [l] The optic nerve and globe are usually resilient to mild-tomoderate ocular trauma, while high-energy trauma can lead to multiple fractures that reduce the orbital volume significantly, facilitating avulsion of the globe from its socket. ${ }^{[4]}$

Globe avulsion is a rare condition usually resulting from severe trauma to the orbit and face. ${ }^{[3]}$ The term describes globes that have been pulled out of their normal anatomical position by an external force. ${ }^{[5]}$ Morris et al. have identified three mechanisms: (a) an elongated object enters the medial orbit, propelling the globe forward; (b) a wedge-shaped object enters the orbit medially, displacing the globe anteriorly; and (c) a penetrating object transects the optic nerve directly. ${ }^{[5]}$ Song and Carter have described abrupt deceleration as a cause of bilateral globe subluxation. ${ }^{[3]}$ Therefore, passengers in the back seats can experience more abrupt deceleration.
Optic nerve transection is well-documented, and it is the major reason for globe subluxation. ${ }^{[2-6]} A n$ isolated ruptured optic nerve is classified as incomplete while it is complete when there is disruption of the extraocular muscles and optic nerve, resulting in total luxation of the ocular bulb. ${ }^{[1]}$ Cases with intact extraocular muscles have been reported. ${ }^{[2-6]}$ The extraocular muscles injured and avulsed most commonly are the medial, inferior, superior, and lateral recti and the obliques, respectively. ${ }^{[7]}$

Imaging studies of the head and orbit are advisable before surgery to assess the extent of orbital and ocular injuries. Brain and orbital CT are required to exclude intracranial bleeding, optic chiasma injury, and bone fractures. ${ }^{[6]}$ Some authors have reported normal CT images in the presence of optic nerve avulsion.

In this case, multiple fractures of the orbital walls and abrupt deceleration likely caused the bilateral globe avulsion. The patient had bilateral transected optic nerves, and none of the extraocular muscles in either globe were intact. He also had multiple fractures corresponding to a Le Fort III pattern with Le Fort II components with frontal sinus anterior wall fractures. There was minor brain edema. 
The management of an avulsed globe is controversial. Some authors advocate primary enucleation to treat ocular globe luxation with optic nerve avulsion because there is no visual recovery. ${ }^{[]]}$Others suggest that repositioning the globe and retaining the eye can offer psychological and cosmetic benefits to the patient ${ }^{[1,2]}$ and enhance the subsequent cosmetic outcome of an ocular prosthesis. ${ }^{[l]}$ Moreover, in children, the maintenance of the ocular globe assists in adequate facial bone development. ${ }^{[8]}$

In this case, the left globe was unsuitable for repositioning, it was enucleated. Then, the right globe was repositioned after repairing the medial and inferior rectus muscles and performing a right lateral canthoplasty. Facial fractures were repaired with plates and screws. The possible mechanism of the survival of the right globe was out of the orbit with soft tissue attachments to the orbital walls and the periorbital soft tissues. At the end of the one year period, there was not any sign of phtisis bulbi, which was due to possible source of the blood supply in the soft tissue attachments. At six months, an ocular prosthesis was placed in the left orbit.

\section{Conclusion}

Globe avulsion is an extremely rare, challenging and unexpected complication of maxillofacial trauma. Patients with severe maxillofacial trauma should be observed meticulously for globe avulsion. Well-repaired fractures and repositioning of the globes prevent facial deformity in children and might reduce the patient's psychological stress due to the concurrent blindness.

No grants and funding have been received for this study.

None of the authors has financial interest related to this study to disclose.

Conflict of interest: None declared.

\section{REFERENCES}

1. Unal S, Argin A, Arslan E, Demirkan F, Aksoy A. Bilateral complete avulsion of ocular globes in a Le Fort III maxillofacial fracture: a case report and review of the literature. Eur J Ophthalmol 2005;15:123-5.

2. Razmjua H, Masjedi M. Traumatic bilateral globe avulsion (case report). J Res Med Sci 2009;14:259-60.

3. Song A, Carter KD. Bilateral traumatic globe subluxation. Ophthal Plast Reconstr Surg 2006;22:136-7. CrossRef

4. Bajaj MS, Kedar S, Sethi A, Gupta V. Traumatic globe luxation with optic nerve transection. Orbit 2000;19:165-170. CrossRef

5. Morris WR, Osborn FD, Fleming JC. Traumatic evulsion of the globe. Ophthal Plast Reconstr Surg 2002;18:261-7. CrossRef

6. de Santana Santos T, Vajgel A, Ribeiro CF, de Santana Júnior JR, Andrade Filho ES. Avulsion of globe following maxillofacial trauma. J Craniofac Surg 2012;23:1097-100. CrossRef

7. Mailer CM. Avulsion of the inferior rectus. Can J Ophthalmol. 1974;9:262-6.

8. Pereira FJ, Bettega RB, Velasco e Cruz AA. Management of globe luxation followed by traumatic liquoric fistula: case report. Arq Bras Oftalmol 2011;74:58-60.

\section{OLGU SUNUMU - ÖZET}

\section{Motorlu taşıt kazalarının nadir görülen bir komplikasyonu: İki taraflı glob avülsiyonu}

Dr. Osman Kelahmetoğlu, ${ }^{*}$ Dr. Tekin Şimşek, ${ }^{2}$ Dr. Ümit Beden, ${ }^{3}$

Dr. İlhami Oğuzhan Aydoğdu, ${ }^{2}$ Dr. Ebru Cömert Hamzaoğlu ${ }^{3}$

${ }^{1}$ Tarsus Devlet Hastanesi, Plastik, Rekonstrüktif ve Estetik Cerrahi Kliniği, Mersin

${ }^{2}$ Ondokuz Mayıs Üniversitesi Tıp Fakültesi, Plastik, Rekonstrüktf ve Estetik Cerrahi Anabilim Dalı, Samsun

${ }^{3}$ Ondokuz Mayıs Üniversitesi Tıp Fakültesi, Göz Hastalıkları Anabilim Dalı, Samsun

Glob avülsiyonu, ağır maksillofasiyal travmalar sonucu oluşabilen nadir bir durumdur. Birkaç tane iki taraflı olarak rapor edilmiş olgular mevcuttur. Bu yazıda, motorlu taşıt kazası sonrası acil servise getirilen bu zorlu duruma sahip I 5 yaşında erkek hasta sunuldu.

Anahtar sözcükler: Avülsiyon; glob; iki tarafl;; luksasyon; travma.

*Şimdiki Kurumu: Bezmialem Vakıf Üniversitesi Tıp Fakültesi, Plastik, Rekonstrüktif ve Estetik Cerrahi Anabilim Dalı, İstanbul

Ulus Travma Acil Cerrahi Derg 2015;2I (4):297-299 doi: 10.5505/tjtes.20I5.5870। 